\title{
Preparation, Characterization of Copper Complex and its Biological Activity
}

Samar A. Aly*1, Hanaa El-Boraey², Ayman S. Eldourghamy ${ }^{1}$ and Amal Mosbah'.

${ }^{1}$ Department of Environmental Biotechnology, Genetic Engineering and Biotechnology Research Institute, University of Sadat City, Egypt.

${ }^{2}$ Department of Chemistry, Faculty of Science, Menoufia University, Shebin El- Kom, Egypt

*Corresponding author: E-mail: samarchem@yahoo.com

\begin{abstract}
Thiosemicarbazones and their metal complexes are very promising compounds which present awide range of pharmacological applications as antimicrobial, antiparasital, and antiviral agents In many circumstances the pharmacological activity of thiosemicarbazones increases upon coordination to metal ions. A new novel copper complex of thiosemicarbazide ligand has been prepared and characterized by different physical and chemical methods such as ${ }^{1} \mathrm{H}$ NMR Spectroscopy, IR spectra, elemental analysis, molar conductance, electronic spectra and magnetic susceptibilities measurements. Copper complex behaves as a neutral tridentate in nature, coordination takes place via carbonyl oxygen, $\mathrm{N}(2) \mathrm{H}$ and $\mathrm{C}=\mathrm{S}$ respectively. Also the study of the effect of gamma irradiation on ligand and $\mathrm{Cu}(\mathrm{I})$ complex using different measurments devices. On the other side, the antibacterial activity of ligand and $\mathrm{Cu}(\mathrm{l})$ complex against gram positive (Streptococcus pyogenes) and gram negative( Escherichia coli) bacteria was investigated. The result revealed that $\mathrm{Cu}(\mathrm{I})$ complex after gamma irradiation showed a higher antibacterial activity against gram positive (Streptococcus pyogenes) and gram negative(Escherichia coli) bacteria than the ligand
\end{abstract}

Keywords: Copper complex, IR, Thermal analysis, Antibacterial, Gamma irradiation

\section{INTRODUCTION}

Thiosemicarbazones are Schiff based ligands which have gained importance over the decades as potential drug candidates. When coordinated to metals, they have proved as good anticancer, antimicrobial, antioxidant and antiprotozoal agents. Transition-metal based complexes hold several advantages over other metal complexes because of their better acceptability and low toxicity in biological systems ( Tahmeena et al 2015).

Thiosemicarbazone derivatives are of special importance because of their versatile biological and pharmacological activities.
Thiosemicarbazone derivatives have found application in drug development for the treatment of central nervous system disorders, of bacterial infection, as well as analgesic and antiallergic agent. Thiosemicarbazones are potent intermediates for the synthesis of pharmaceutical and bioactive materials and thus, they are used extensively in the field of medicinal chemistry. Moreover, thiosemicarbazones have found their way into almost every branch of chemistry; commercially they are used as dyes, 
photographic films, plastic and in textile industry ( Tada et al 2011).

Our aim in this research work to prepare, characterized of copper(I) complex of thiosemicarbazide ligand by using different spectral, physical measurements before and after gamma irradiation and also antibacterial activity of ligand and $\mathrm{Cu}(\mathrm{I})$ complex before and after gamma irradiation were investigated against two pathogenic bacteria Streptococcus pyogenes as Gram-positive bacteria and Escherichia coli as Gram-negative bacteria to assess their antibacterial activity .

\section{MATERIALS AND METHODES}

\section{Material}

All reactions were carried out under normal atmospheric conditions. All the chemicals used in this study were of AnalaR grade and procured from Sigma, Aldrich and Fluka. Metal salts (E.Merck).

\section{Synthesis of Ligand}

The ligand of $p$-toludine-phenylisothio cyanate $\left(\mathrm{H}_{2} \mathrm{~L}\right)$ was prepared by mixing $(0.01$ $\mathrm{mol})$ of desired hydrazide with $(0.01 \mathrm{~mol})$ of phenyl isothiocyanate in $15 \mathrm{ml}$ of absolute ethanol. The reaction mixture was refluxed for 6 hrs. The reaction mixture was recrystalized several times from ethanol

\section{Synthesis of Copper(I) Complex}

Copper(I) complex of the ligand $p$ toludine-phenyl isothiocyanate was prepared by adding stoichiometric amount of the $\mathrm{Cul}$ in $\mathrm{EtOH}$ to a hot solution of $\left(\mathrm{H}_{2} \mathrm{~L}\right)$ in $\mathrm{EtOH}$ in a 1:1 molar ratio. The reaction solution was stirred magnetically at for certain about 6hrs. The resulting solids were filtered off, washed several times with $\mathrm{EtOH}$ and dried under vacuum over $\mathrm{P}_{4} \mathrm{O}_{10}$.

\section{Measurements}

Elemental analyses $(\mathrm{C}, \mathrm{H}$ and $\mathrm{N})$ were performed by Microanalytical unit of the Cairo Univerisity, Egypt.Metal and chlorides were estimated using standard methods

(Elboraey and El-Gammal 2015). IR absorption spectra were recorded using $\mathrm{KBr}$ discs and a Perkin-Elmer 1430 recording spectrophotometere. ${ }^{1} \mathrm{H}$ NMR spectra were recorded in d6-DMSO using $300 \mathrm{MHz}$ Varian NMR spectrometer. The electronic spectra were carried out as solution $\left(10^{-3} \mathrm{M}\right)$ in DMF using a Perkin- Elmer Lambada 4B spectrophotometer. The molar conductivity measurements were made in DMF solution $\left(10^{-3} \mathrm{M}\right)$ using a Tacussel conductometer type CD6N. Magentic susceptibilities were measured at $27 \mathrm{C}^{\circ}$ using a modified Gouy method with Johnson Mattey balance. Energetic $y$-irradiation exposure was undertaken using a $\mathrm{y}^{-} \mathrm{C}^{\circ} 60$ unit at atomic energy establishment AEE at EI-Naser City Egypt at an accumalated dose of 6 Mega rad in air.

\section{Antibacterial tests}

The in vitro antibacterial activity studies were carried out as described by (Elboraey et al, 2016) with some modification, the inhibitory effect of both the synthesized ligand and its complex was tested on the pathogenic Gram-positive organism Streptococcus pyogenes and the Gramnegative bacterium Escherichia coli. Biological effect of the ligand and its complex was carried out before and after exposure to gamma irradiation. Brain Heart Infusion (BHI) was used to grow Streptococcus pyogenes cells and Nutrient broth medium was used to grow $E$. 
coli cells. Compounds under investigation were dissolved in DMSO which has no inhibition activity on both microbes. Two different concentrations $(1 \mu \mathrm{g} / \mathrm{ml}$, and $5 \mu \mathrm{g} / \mathrm{ml})$ were prepared. Bacterial strains were prepared by activating them on the proper broth media with shaking. The bacteria were then cultured for $24 \mathrm{~h}$ at $37 \mathrm{C}^{\circ}$ in an incubator. One $\mathrm{ml}$ of the standard bacterial culture was used as inoculation in a broth medium.

For growth studies, S. pyogenes and E. coli cultures were inoculated and grown aerobically on BHI broth medium and NB medium respectively. Growth was calculated turbidometrically at $650 \mathrm{~nm}$ using conventional Spectrophotometer, in which turbidity produced is measured by taking absorbance and compared with turbidity produced by control.

After growing bacterial cultures on media that contain the ligand, the complex and the control, absorption measurements were accomplished by spectrophotometer after 24 and $48 \mathrm{~h}$ of incubation to determine the number of viable cell count per milliliter of sample and were used to the calculated the inhibition Percentage.

\section{RESULTS and DISCUSSION}

The ligand $\left(\mathrm{H}_{2} \mathrm{~L}\right)$ was confirmed by elemental analysis as shown in table (1), infrared as shown in table (2) and ${ }^{1} \mathrm{H}$ NMR spectroscopy. The reaction of the ligand $\mathrm{H}_{2} \mathrm{~L}$ with Cul produce complex of the general formulae $\left[\mathrm{Cu}\left(\mathrm{H}_{2} \mathrm{~L}\right)\right.$ I.]. These air stable complexes are non-hygroscopic, partially soluble in most organic solvents, but freely soluble in DMF and DMSO. Values of molar conductivities were measured in DMF $\left(10^{-3} \mathrm{M}\right)$ solution. Table (1) shows that, the complex is non-electrolyte, indicating that coordination of the anion to the ligand. The solid complex is colored, insoluble in water, methanol and ethanol but soluble in DMF at $10^{-3} \mathrm{M}$ (AlShaheen and Al-Mula 2014).

Table 1: Analytical and physical data for the ligand $\left(\mathrm{H}_{2} \mathrm{~L}, \mathrm{C}_{16} \mathrm{H}_{18} \mathrm{~N}_{4} \mathrm{OS}\right)$ and $\mathrm{Copper}(\mathrm{I})$ complex

\begin{tabular}{|c|c|c|c|c|c|c|c|}
\hline \multirow{2}{*}{ Compound } & \multirow{2}{*}{ Color } & \multicolumn{6}{|c|}{ Calc. (Found \%) } \\
\hline & & $\mathrm{C}$ & $\mathrm{H}$ & $\mathrm{N}$ & I & $\mathrm{Cu}$ & $\Lambda_{M}$ \\
\hline $\mathrm{H}_{2} \mathrm{~L}$ & $\begin{array}{l}\text { Buff } \\
75\end{array}$ & $\begin{array}{l}61.1 \\
(61.3)\end{array}$ & $\begin{array}{l}5.73 \\
(5.70)\end{array}$ & $\begin{array}{l}17.8 \\
(17.9)\end{array}$ & - & - & - \\
\hline $\mathrm{Cu}\left(\mathrm{H}_{2} \mathrm{~L}\right) \mathrm{I}$ & Green & $\begin{array}{l}38.1 \\
(38.4)\end{array}$ & $\begin{array}{l}3.6 \\
(4.2)\end{array}$ & $\begin{array}{l}11.1 \\
(11.4)\end{array}$ & $\begin{array}{l}25.2 \\
(25.2)\end{array}$ & $\begin{array}{l}12.6 \\
(12.3)\end{array}$ & 25 \\
\hline
\end{tabular}

Where, $\Lambda_{M}=$ molar conductivity ohm-1 $\mathrm{cm}^{2} \mathrm{~mol}^{-1}$ in $10^{-3} \mathrm{M}$ in DMF solution.

\section{The infrared spectra of the ligand and} complex

Fundamental IR spectral bands for the ligand and copper(I) complex before and after gamma-irradiation are given in Table 2 . The IR spectrum of the free ligand is characterized mainly by the strong bands at $3384 \mathrm{~cm}^{-1}, 3262$ $\mathrm{cm}^{-1}, 3150 \mathrm{~cm}^{-1}, 1672 \mathrm{~cm}^{-1}$ and $749 \mathrm{~cm}^{-1}$ are attributed to the stretching frequencies of $\mathrm{U}(\mathrm{N} 4-$ $\mathrm{H}), \mathrm{u}(\mathrm{N} 2-\mathrm{H}), \mathrm{u}(\mathrm{N} 1-\mathrm{H}), \mathrm{u}(\mathrm{C}=\mathrm{O})$ and $\mathrm{u}(\mathrm{C}=\mathrm{S})$ wagging vibrations, respectively(Abou

Sekkina etal., 2011). This supports the nature of the ligand $\mathrm{H}_{2} \mathrm{~L}$ as tridentate one and coordination take place via $(\mathrm{C}=\mathrm{O}),(\mathrm{N} 2-\mathrm{H})$ and $(\mathrm{C}=\mathrm{S})$. The bonding mode of the ligand to metal ions has been judged by a careful Research Journal of Applied Biotechnology, Vol. 4(2), 60-67, 2018. 
comparison of the infrared spectra of the complex with that of the free ligand. In general, the infrared spectra of the metal complex show significant changes compared to the spectrum of the free ligand. The most important diagnostic spectral bands of $\mathrm{Cu}(\mathrm{I})$ complex after and before gamma-irradiation are depicted in Table 2

Table (2): Infrared spectral bands $\left(\mathrm{cm}^{-1}\right)$ for ligand $\left(\mathrm{H}_{2} \mathrm{~L}\right)$ and $\mathrm{Cu}(\mathrm{I})$ complex

\begin{tabular}{|c|c|c|c|c|c|c|c|c|}
\hline No. & Compound & $\begin{array}{c}\mathrm{v}(\mathrm{N} 4-\mathrm{H}) / \\
\mathrm{v}(\mathrm{OH})\end{array}$ & $\mathrm{v}(\mathrm{N} 2-\mathrm{H})$ & $\mathrm{v}(\mathrm{N} 1-\mathrm{H})$ & $\mathrm{v}(\mathrm{C}=\mathrm{O})$ & $\mathrm{v}(\mathrm{C}=\mathrm{S})$ & $\begin{array}{c}\mathrm{v}(\mathrm{Cu}- \\
\mathrm{O})\end{array}$ & $\mathrm{v}(\mathrm{Cu}-\mathrm{N})$ \\
\hline & $\mathrm{H}_{2} \mathrm{~L}$ & 3384 & 3263 & 3150 & 1672 & 749 & - & - \\
\hline & $\mathrm{H}_{2} \mathrm{~L}^{*}$ & 3336 & 3185 & 3126 & 1689 & 750 & - & - \\
\hline $\mathrm{B}_{1}$ & $\mathrm{Cu}\left(\mathrm{H}_{2} \mathrm{~L}\right) \mathrm{I}$ & 3431 & 3293 & 3183 & 1597 & 749 & 601 & 529 \\
\hline $\mathrm{A}_{1}$ & $\mathrm{Cu}\left(\mathrm{H}_{2} \mathrm{~L}\right) I^{*}$ & 3434 & 3295 & 3185 & 1597 & 750 & 602 & 529 \\
\hline
\end{tabular}

Where * after gamma irradiation (6Mega rad)

The IR spectra $\mathrm{Cu}(\mathrm{I})$ complex show strong bands at 3431-3434 cm-1, 3293-3295 $\mathrm{cm}^{-1}, 3183-3185 \mathrm{~cm}^{-1}$ and $749-, 750 \mathrm{~cm}^{-1}$ which attributed to the stretching frequencies of $\mathrm{u}(\mathrm{N} 4-\mathrm{H}), \mathrm{u}(\mathrm{N} 2-\mathrm{H}), \mathrm{u}(\mathrm{N} 1-\mathrm{H}), \mathrm{u}(\mathrm{C}=\mathrm{O})$ and $\mathrm{U}(\mathrm{C}=\mathrm{S})$ wagging vibrations, respectively. By comparing the IR spectra of $\mathrm{Cu}(\mathrm{I})$ complex before and after gamma irradiation display that the band corresponding to $\mathrm{U}(\mathrm{N} 2-\mathrm{H})$ after gamma irradiation shift to higher frequency as compared of $\mathrm{Cu}(\mathrm{I})$ complex before gamma irradiation and high intensity of the bands of function groups after gamma irradiation. The new bands appeared at $601-602 \mathrm{~cm}^{-1}$ and $529 \mathrm{~cm}^{-1}$ assigned to $\mathrm{U}(\mathrm{M}-\mathrm{O})$ and $\mathrm{u}(\mathrm{M}-\mathrm{N})$ respectively(Meena and Jain 2014).

\section{${ }^{1} \mathrm{H}$ NMR Spectra}

The ${ }^{1} \mathrm{H}$ NMR spectrum of the ligand $\left(\mathrm{H}_{2} \mathrm{~L}\right)$ in DMSO $-\mathrm{d}^{6}$ revealed a chemical shift (ठ/ppm) at $9.045 \mathrm{ppm}$ and at $9.733 \mathrm{ppm}$ attributed to $\mathrm{N}(4) \mathrm{H}$ and $\mathrm{N}(1) \mathrm{H}$. The peaks of $\mathrm{N}(1) \mathrm{H}$ and $\mathrm{N}(2) \mathrm{H}$ appeared as signals at 8.9 and $8.3 \mathrm{ppm}$.The singlet peak appeared at $3.331 \mathrm{ppm}$ due to $\mathrm{CH}_{2}$ group and the multiple peak at $7.4 \mathrm{ppm}$ due to aromatic protons of phenyl group (El-Saied et al., 2017).

\section{The electronic spectra of the ligand and copper(I) complex}

The electronic spectra of ligand and $\mathrm{Cu}(\mathrm{I})$ complex were recorded in DMF solution $\left(10^{-3} \mathrm{M}\right)$. In UV spectra of ligand shows $\lambda_{\max }$ at $272 \mathrm{~nm}$ with a shoulder band. It indicates that in DMF solution the ligand exists in thiol form. While in $\mathrm{Cu}(\mathrm{I})$ ions have the $\mathrm{d}^{10}$ configuration and therefore their complexes should not exhibit any $d$ - $d$ transition. The copper complex of this ion was found to be diamagnetic and octahedral geometry (Haddad et al. 2013).

Thermal Studies (TGA) before and after $Y$ Irradiation

The thermal behavior of the ligand and $\mathrm{Cu}\left(\mathrm{H}_{2} \mathrm{~L}\right) I, \mathrm{Cu}\left(\mathrm{H}_{2} \mathrm{~L}\right) I^{*}$ complexes synthesized before and after $\mathrm{y}$-irradiation are shown and Figs.(1 and 2). The thermal behavior of the ligand and copper complexes before and after $\mathrm{Y}$-irradiation was investigated by thermogravimetric studies in temperature range $25-800{ }^{\circ} \mathrm{C}$. The nature of proposed chemical change with temperature and percent of metal oxide obtained shown in Figs.(1 and 2) 
The ligand before and after $\mathbf{y}$-irradiation

The TG curve of the ligand before and after $y$-irradiation shows that it is thermally stable till $140^{\circ} \mathrm{C}$. Also the TG curve shows three decomposition steps (Fig.1) in the temperature range $140-550^{\circ} \mathrm{C} ; 125-510^{\circ} \mathrm{C}$ with total weight loss of Calc. $99.0 \%$ (Found 99.9\%); Calc.100\% (Found 100\%) before and after $\mathrm{Y}$-irradiation respectively. Before $\mathrm{Y}$ irradiation the thermogravimetric analyses curves of the ligand reveal that gamma irradiation induced thermal stability to the material than after irradiation (Abousekkina et al., 2011). These results agree well with the composition of the ligand determined from elemental analysis and IR spectrum.

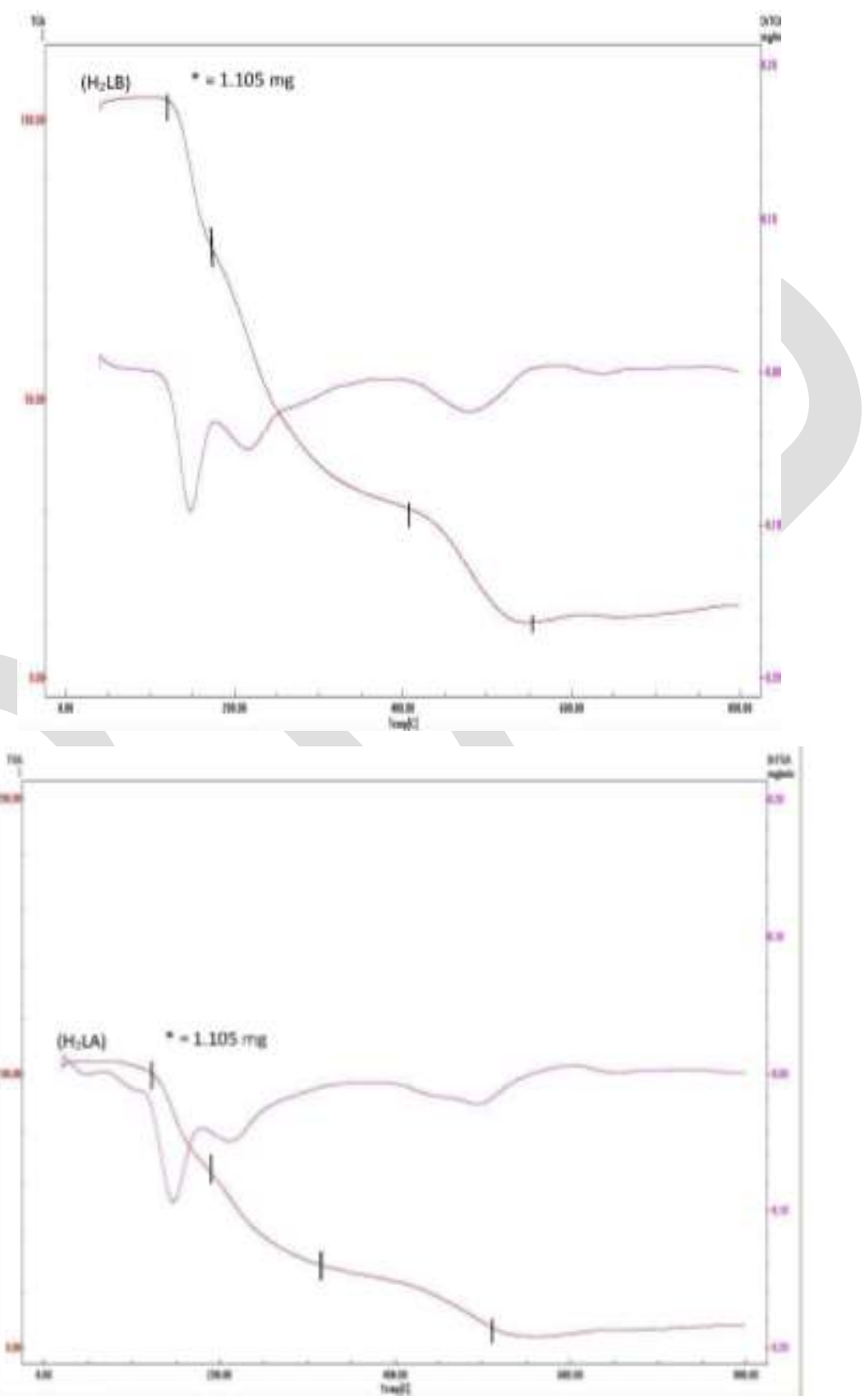

Fig .1: TGA/ DTG curves of ligand before irradiation $\left(\mathrm{H}_{2} \mathrm{~L}_{B}\right)$, after irradiation $\left(\mathrm{H}_{2} \mathrm{~L}_{A}\right)$ 
Copper complexes before and after $\mathrm{Y}$ - $\quad$ TG curve exhibit gradual decomposition at a irradiation

The TGA curve of copper complexes before temperature range $195-570^{\circ} \mathrm{C}$, leaving $\mathrm{CuO}$ and after $\mathrm{Y}$ - irradiation ( $B_{1}$ and $\left.A_{1}\right)$ (Fig.2). The as final residue at $570^{\circ} \mathrm{C}$. The TG curve after $\mathrm{Y}$-irradiation is similar to before $\mathrm{Y}$-irradiation.

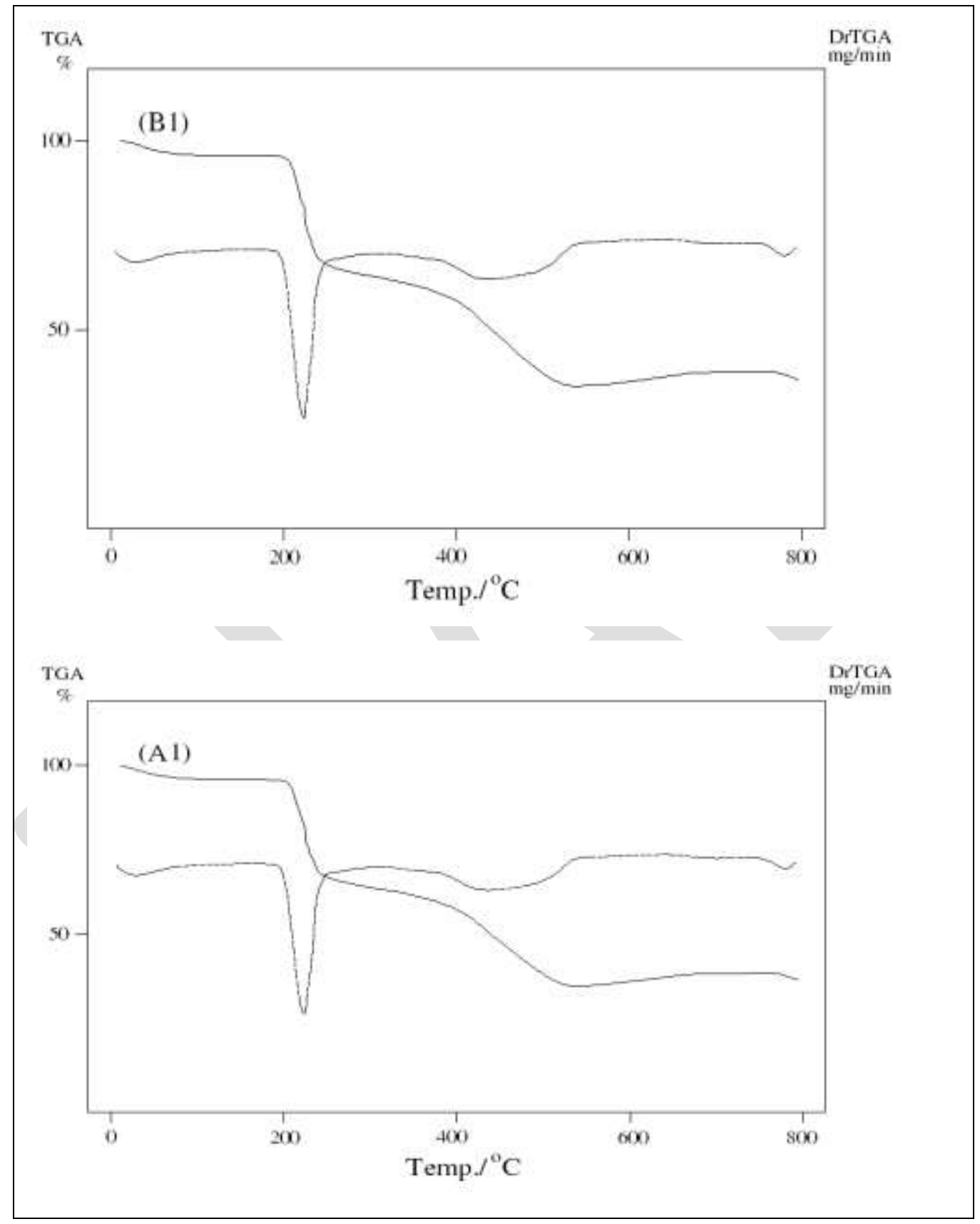

Fig. 2: TGA/ DTG curves of copper complexes before irradiation $\left(B_{1}\right)$, after irradiation $\left(A_{1}\right)$

Antibacterial Activity:

The antibacterial studies of the prepared compounds screened against both gram-positive and gram-negative bacteria proved that these compounds exhibit remarkable antibacterial activity and can be used in the future as therapeutic drugs for pathogenic bacterial diseases in table(3) showed antibacterial activity against the tested microbes. Generally, it was found that the antibacterial activity of both the synthetic ligand and $\mathrm{Cu}(\mathrm{I})$ complex was proportionally 
increased with increased concentration. The tested compounds are found to have remarkable biological activity. For $1 \mu \mathrm{g} / \mathrm{ml}$ concentration of both synthetic ligand and $\mathrm{Cu}(\mathrm{I})$ complex, the antibacterial activity of the tested compounds was found to follow the order : $\mathrm{Cu}(\mathrm{I})$ complex < ligand in case of $E$. coli as shown in figure (4). On the other hand, a higher antibacterial activity was recorded when using the ligand with $S$. pyogenes as shown in figure (3) with the same concentration. (Elboraey et al., 2016).

Antibacterial activity of $5 \mu \mathrm{g} / \mathrm{ml}$ concentration for both the free acyclic ligand and its complex followed the order ligand complex when compounds were used with both S. pyogenes and E. coli (Sönmez et al., 2010). Results in Figure (4) suggested that in case of $1 \mu \mathrm{g} / \mathrm{ml} \mathrm{Cu}(\mathrm{I})$ complex, the chelation could facilitate the ability to cross the cell membrane of $E$. coli and can be explained by Tweedy's chelation theory. Chelation complication could enhance the lipophilic nature of the central metal atom, which subsequently favors its permeation through the lipid layer of the cell membrane (Tweedy, 1964). Complex when used with both concentrations $(1 \mu \mathrm{g} / \mathrm{ml}$ and $5 \mu \mathrm{g} / \mathrm{ml})$ in case of the gram-positive $S$. pyogene bacterium. It also has been observed that some moieties such as $\mathrm{N}(2) \mathrm{H}$ linkage introduced into such compounds exhibits extensive biological activity (Singh et al., 2013). The antibacterial studies of the prepared compounds screened against both gram-positive and gram-negative bacteria proved that these compounds exhibit remarkable antibacterial activity and can be used in the future as therapeutic drugs for pathogenic bacterial diseases.

Table (3): Antibacterial activity of ligand and its metal complex

\begin{tabular}{|c|c|c|c|c|}
\hline \multirow{2}{*}{ Compound } & \multicolumn{4}{|c|}{ Inhibition \% } \\
\cline { 2 - 5 } & $1 \mu \mathrm{g} / \mathrm{ml}$ & $5 \mu \mathrm{g} / \mathrm{ml}$ & $1 \mu \mathrm{g} / \mathrm{ml}$ & $5 \mu \mathrm{g} / \mathrm{ml}$ \\
\hline $\mathrm{H}_{2} \mathrm{~L}_{2}$ & 48.76 & 56.23 & 75.32 & 91.24 \\
\hline $\mathrm{H}_{2} \mathrm{~L}_{2}^{*}$ & 52.11 & 66.76 & 74.40 & 95.32 \\
\hline $\mathrm{Cu}\left(\mathrm{H}_{2} \mathrm{~L}\right) \mathrm{I}$ & 86.44 & 92.13 & 57.66 & 88.3 \\
\hline $\mathrm{Cu}\left(\mathrm{H}_{2} \mathrm{~L}\right) 1^{*}$ & 82.8 & 86.50 & 83.41 & 94.31 \\
\hline
\end{tabular}




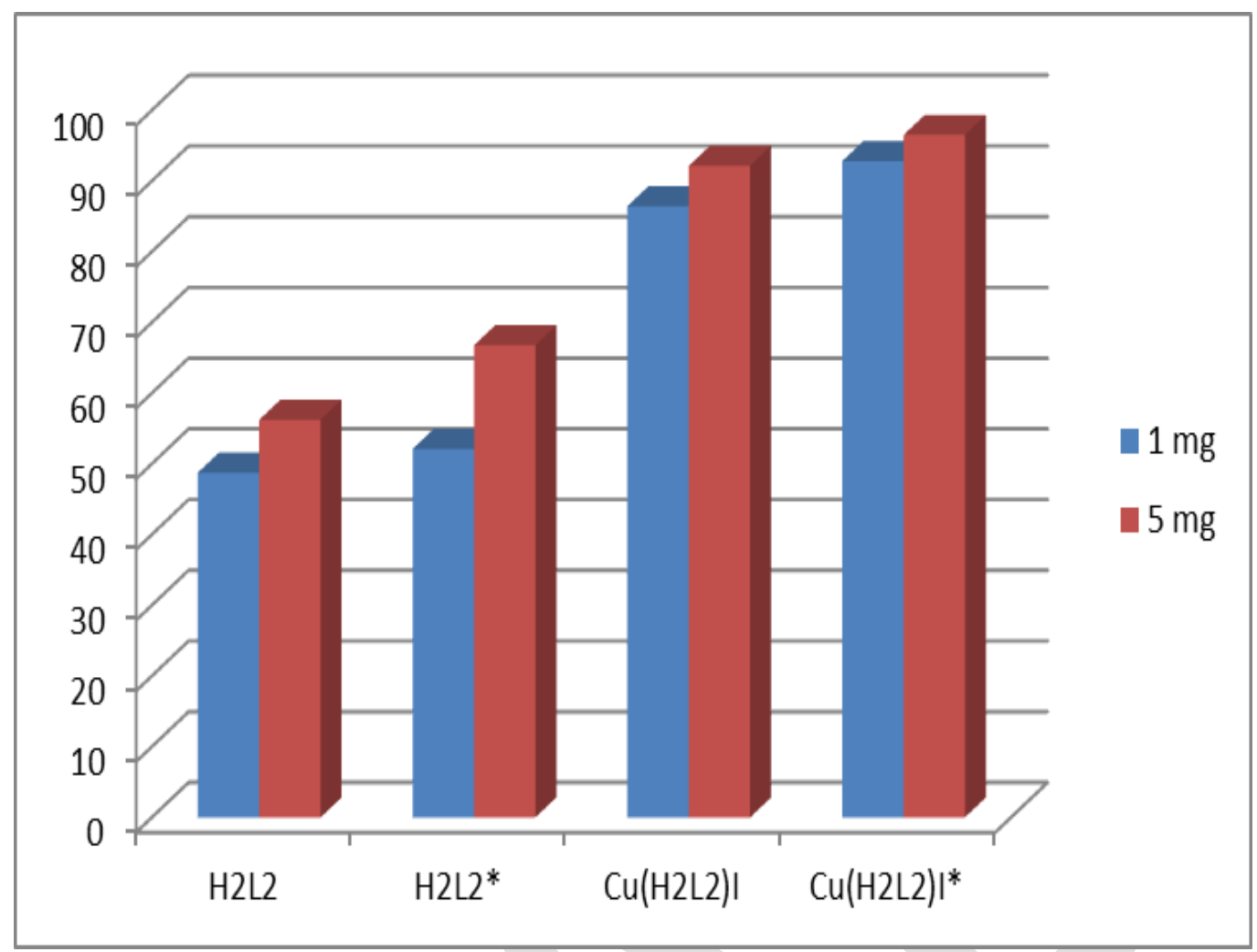

Fig.3: antibacterial activity of ligand and copper(I) complex against S. Pyogenes before and after irradiation.

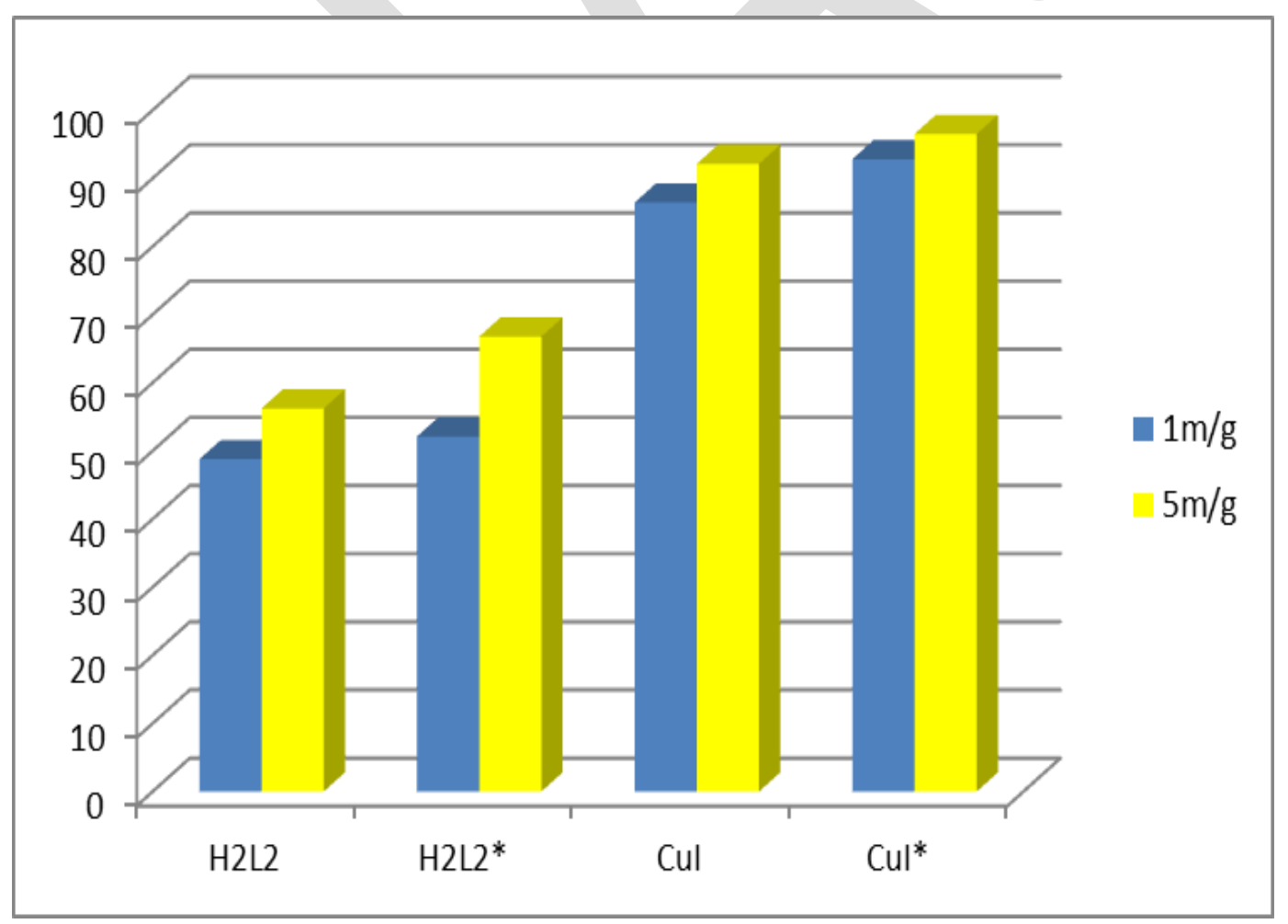

Fig. 4: Antibacterial activity of ligand and copper (I) complex against E.coli before and After irradiation. 


\section{CONCLUSION}

In this study we prepared $\mathrm{Cu}(\mathrm{I})$ complex which is in the agreement with the proposed structure and study the effect of gamma irradiation on $\mathrm{Cu}(\mathrm{I})$ complex by using physicochemical and spectral measurements before and after gamma irradiation and the study proved that:

1- The spectral analysis of infrared using $\mathrm{Y}$-ray showed that effective bands to groups growing larger and stronger than before irradiation.
2- Low wave length of complex after gamma irradiation than before gamma irradiation

3- The activity of antibacterial of $\mathrm{Cu}(\mathrm{I})$ after gamma irradiation was increased than before gamma irradiation.

\section{REFERENCES}

AbouSekkina, M. M. A., Kashar, T. I., and Aly, S. A. (2011): Spectrochemical study and effect of high energatic gamma ray on copper(II) complexes. Solid State Sciences, 13, 2080-2085.

Al-Shaheen J. A. and Al-Mula A. M. (2014): Schiff Base Complexes of $\mathrm{Fe}$ (III) Derived from Amino Acids. Research Journal of Chemical Sciences , 4, 25-32.

El-Boraey H. A. and El-Gammal O. A. (2015): New 15-membered tetraaza ( $N$ 4) macrocyclic ligand and its transition metal complexes: spectral, magnetic, thermal and anticancer activity. Spectrochimica Acta Part A: Molecular and Biomolecular Spectroscopy, 138, 553-562.

El-Boraey H. A., El-Salamony M. A. and Hathout A. A. (2016):
Macrocyclic [N5] transition metal complexes: synthesis, characterization and biological activities. Journal of Inclusion Phenomena and Macrocyclic Chemistry, 86, 153-166.

El-Saied F. A., Al-Hakimi A. N. and Wahba M. W. (2017): Preparation, Characterization and Antimicrobial Activities of N'((3-(hydroxyimino) butan-2ylidene)-2 (phenylamino) acetohydrazide and Its Metal Complexes. Egypt. J. Chem. $60,1-24$

Meena S. K. and Jain M. (2014): Synthesis, spectral studies and antimicrobial screening of some transition metal complexes with substituted acetophenone thiosemicarbazone. International Journal of Pharmaceutical Sciences and Research, 5(11), 4880. 
Naohiro T., Takanori I., Tomoya K., Hiroki

S., Setsu

S., Keiji

I. and Yasuhiro Y. (2011):

Deposition Mechanism and

Electrical Property of

$\mathrm{CeO}_{2}$ Thin Films by MOCVD

with $\mathrm{H}_{2} \mathrm{O}$ Introduction.ECS.,

41, 220-228. Julia R. Köhler

Raghad H., Emad Y. and Ahmed A. (2013):

Synthesis and characterization of transition metalcomplexes of 4-Amino-5-pyridyl-4H-1,2,4triazole-3-thiol. SpringerPlus , 2, 510-516.

Singh D. P., Grover V., Rathi P. and Jain K. (2013): Trivalent transition metal complexes derived from carbohydrazide and dimedone. Arabian Journal of Chemistry, 10, S1795-S1801.
Sönmez M., Celebi M. and Berber I. (2010): Synthesis, spectroscopic and biological studies on the new symmetric Schiff base derived from 2, 6-diformyl-4methylphenol with $\mathrm{N}$ aminopyrimidine. European journal of medicinal chemistry, 45, 1935-1940.

Tahmeena C. and Julia R. K. (2015): Ribosomal protein S6 phosphorylation is controlled by TOR and modulated by PKA in Candida albicans. Molecular Microbiology, 98, 384-402.

Tweedy B. G. (1964): Plant extracts with metal ions as potential antimicrobial agents. Phytopathology, 55, 910-914. 